UDC: 159.95

DOI: https://doi.org/10.24195/2414-4665-2017-7-15

\author{
Natalia Dmitrenko, \\ PhD (Candidate of Pedagogical Sciences), associate professor, \\ Department of Teaching Methods of Foreign Languages, \\ Vinnytsia State Pedagogical University named after Mykhailo Kotsiubynskyi, \\ 32, Ostrozkoho Str., Vinnytsia, Ukraine \\ Luydmila Krupelnytska, \\ Doctor of Psychology, associate professor, \\ Department of Psychodiagnostics and Clinical Psychology, \\ Taras Shevchenko National University of Kyiv, \\ 16, Shevchenko Bul., Kyiv, Ukraine \\ Oksana Shportun, \\ PhD (Candidate of Pedagogical Sciences), \\ Doctoral Student, Department of Psychodiagnostics and Clinical Psychology, \\ Taras Shevchenko National University of Kyiv, \\ 16, Shevchenko Bul., Kyiv, Ukraine
}

\title{
PERCEPTION OF HUMOROUS CONTENT UNDER NORMAL AND PSYCHOPATHOLOGICAL CONDITIONS
}

The article presents the results of the study of perception of humorous content by individuals who belong to the group of conventional norm and by people with mental disorders. The survey involved 358 respondents with psyhcopathologies and 52 healthy respondents and was based on Humorous Statements Assessment Inventory. The perception of humour by the group of individuals who represent different nosological forms differs inside the group in comparison with the group of individuals of conventional norm. Since the specificity of perception of humorous content by people in conventional norms and people with various mental disorders is different, the use of humor has a pcychodiagonostical orientation in detecting of certain mental pathologies. For instance, the participants with paranoid schizophrenia and dysthymia show an exact tendency to underestimating the humour of phrases. The comments of the phrases by the respondents with dysthymia show the reduction of motives and desires, lack of energy aspects of psyche to adequate respond to humour. The patients with cyclotemia show a tendency to overestimate the humour of the proposed content. The patients with mental retardation of light degree show a tendency to underestimating some humorous phrases and overestimating others. Precisely this tendency is manifested by individuals with mental retardation of moderate degree and reflects, above all, the lack of understanding of humorous content. Groups of people with neurotic, stress-related and somatoform disorders and Asperger syndrome do not show significant differences in the assessment of humorous content as compared to the participants of the group of conventional norm.

Keywords: perception of humour, humorous content, group of conventional norm, group of individuals with mental disorders.

\section{Introduction}

The character of perception of humorous content is an important parameter, which can help to diagnose the development of certain types of pathology. Even indistinct mental violation or changes in the functioning of brain structures are reflected on the peculiarities of perception of humorous products. That is why this aspect of humour attracts the attention of researchers [1-8]. But still there are few studies which present data on specific perception of humorous content by individuals with different types of mental disorders, so this issue remains understudied.

The paper aims to present the research results of perception of humorous content in norm and psychopathology.

\section{Research Methods}

The experiment involved 358 patients of Vinnytsia Regional Psychiatric Hospital named after O. Yushchenko and Vinnytsia Regional Drug Abuse
Clinic "Sociotherapy". Among them: with paranoid schizophrenia (F20.0) - 24 people; cyclotemia (F-34.0) 33 people; dysthymia (F-34.1) - 42 people; with neurotic, stress-related disorders (F-40 - F-48) - 124 people; neurasthenia - 25 people; obsessive-compulsive disorders 26 people; hypochondria disorder -25 people; dissociative converse disorders - 26 people; mixed anxiety and depressive disorder - 22 people; mental and behavioural disorders due to psychoactive substance use (MBDPSU) (F-10 - F-19) - 65 people, in particular, mental and behavioural disorders due to alcohol use (MBDAU) -30 people, mental and behavioural disorders due to opioids use (MBDOU) - 35 people; mental retardation $(\mathrm{F}-70-\mathrm{F}-$ 79) -50 people, notably, with diagnose mental retardation of light degree (F-70) - 29 people, mental retardation of moderate degree $(\mathrm{F}-71)-21$ people; Asperger syndrome (F-84.5) - 20 people. 
The age of participants ranged from 18 to 54 years $(\mathrm{M}=31.1, \mathrm{SD}=6.2)$.

The group of conventional norm included: lecturers of Vinnytsia State Pedagogical University named after M. Kotsiubynskyi (52 people), lawyers of Vinnytsia Regional Law Association - 64 people, telecommunication experts of "Vita" Television Company - 28 people, and medical employees of Vinnytsia Regional Clinical Hospital named after M. Pirogov, Department of Traumatology - 60 people. The age of people who joined the group of conventional norm ranged from 25 to 71 years $(\mathrm{M}=32.4, \mathrm{SD}=$ 6.3).

The survey was based on the Assessment of Humorous Statements Inventory developed by M. Koviazina and M. Kohan [3]. It includes 50 statements: 38 humorous statements and 12 neutral phrases. The participants were suggested to listen to the phrases and assess the extent of humour of each one using a scale from 0 (unfunny) to 5 (very funny).

While processing the results we also grounded on the authors' data of the approbation of the technique on healthy respondents. Firstly, authors distinguished "funny" and "neutral" phrases from their point of view. Later, they performed the analysis of frequency of statements assessment. Thus, out of 38 so-called "funny" phrases the authors obtained 21, which were assessed as comic and received 3, 4 or 5 points by more than $60 \%$ of test participants. These are phrases 5, 7, 10, 12, 13, 14, 18, 24, 25, 29, 32, 34, 36, 38, 40, 41, 44, 45, 46, 48, and 50 [Annex A]. The authors referred them to pure humorous (funny) statements. Among 29 phrases that were not included according to the frequency analysis to the category of "funny", 18 phrases were considered by the respondents as "neutral" and assessed in 0 points $(4,6,11,16,19,23$, $26,43,47)$ and "not very funny" -1 or 2 points $(1,2,15$, 21, 22, 30, 35, 39, 49) [Annex A]. The phrases remained were placed in the medium category: $50 \%$ of them were assessed as "humorous", and the other $50 \%$ as "not funny". These phrases were not used by the authors in the further analysis of the results.
We have not removed "not very funny" phrases, as they can also present research interest. There is a probability that individuals with mental disorders perceive them in a different way as compared with healthy individuals.

The comparison of data obtained in the study of people with mental disorders and healthy people provided an opportunity to explore the specificity of perceptive aspect of humour, depending on the form of nosology. Using the described methods, we compared the results of statements assessment included in the proposed set which was done by the authors' and our respondents.

Distribution of the respondents by the criterion of assessing statements as "funny", "not very funny" or "neutral" was similar to obtained by the authors of the technique. $64.6 \%$ of the respondents assessed phrases $5,7,10$, $12,13,14,18,24,25,29,32,34,36,38,40,41,44,45$, 46,48 , and 50 as "funny" (assessed in 3,4 or 5 points; the authors' result was about more than $60 \%$ ); $62.1 \%$ of the respondents assessed phrases $4,6,11,16,19,23,26,43$, 47 as "neutral" (evaluated them in 0 points), and phrases $1,2,15,21,22,30,35,39,49$, as "not very funny" (evaluated them in 1 or 2 points) [Annex A]. Differences in perception of statements depending on the professional affiliation and gender were not detected. Thus, the respondents who belong to the group of conventional norm perceive the statements similarly to the individuals who participated in the study of the authors of the technique.

In the process of further analysis, we compared these points with the points by people with mental disorders in order to find probable differences in perceptive aspect of humour by individuals with mental disorders and healthy people. The comparison was carried out separately for each phrase. We compared points of the group of conventional norm with the points of groups formed by the criterion of nosological diagnosis, i.e. groups of people with paranoid schizophrenia, cyclotemia, dysthymia, neurotic, stress-related and somatoform disorders, mental retardation, Asperger syndrome, MBDAU, MBDOU (Table 1).

Comparison of medians of assessment of humorous statements

Table 1.

by people with mental disorders and the group of conventional norm

\begin{tabular}{|c|c|c|c|c|c|c|c|c|c|c|}
\hline \multirow{2}{*}{$\begin{array}{c}\text { \# state- } \\
\text { ment }\end{array}$} & \multicolumn{10}{|c|}{ Medians of Assessment } \\
\hline & Norm & F20.0 & F34.0 & F34.1 & F40- F48 & F10 & F11 & F70 & F71 & F84.5 \\
\hline 5 & 3 & 2 & 4 & 2 & 3 & 2 & 2 & 2 & 1 & 3 \\
\hline 7 & 3 & 3 & 4 & 2 & 3 & 4 & 3 & 2 & 1 & 4 \\
\hline 10 & 4 & 4 & 4 & 2 & 4 & 3 & 3 & 4 & 0 & 4 \\
\hline 12 & 3 & 2 & 4 & 2 & 3 & 4 & 3 & 4 & 3 & 4 \\
\hline 13 & 4 & 3 & 4 & 3 & 4 & 4 & 4 & 3 & 1 & 2 \\
\hline 14 & 4 & 2 & 4 & 2 & 4 & 4 & 4 & 2 & 4 & 3 \\
\hline 18 & 3 & 2 & 4 & 3 & 4 & 4 & 4 & 4 & 3 & 4 \\
\hline 24 & 3 & 3 & 3 & 2 & 3 & 3 & 3 & 2 & 3 & 3 \\
\hline 25 & 3 & 2 & 4 & 2 & 3 & 4 & 3 & 2 & 1 & 4 \\
\hline 29 & 3 & 2 & 4 & 2 & 4 & 4 & 3 & 4 & 0 & 2 \\
\hline 32 & 4 & 2 & 4 & 3 & 4 & 3 & 3 & 3 & 0 & 3 \\
\hline 34 & 4 & 3 & 4 & 2 & 4 & 4 & 4 & 3 & 1 & 3 \\
\hline 36 & 3 & 3 & 4 & 2 & 3 & 3 & 3 & 4 & 2 & 2 \\
\hline 38 & 3 & 3 & 4 & 2 & 3 & 3 & 3 & 2 & 4 & 4 \\
\hline 40 & 4 & 1 & 4 & 3 & 4 & 4 & 3 & 3 & 0 & 3 \\
\hline 41 & 3 & 3 & 4 & 2 & 3 & 3 & 3 & 2 & 2 & 1 \\
\hline
\end{tabular}




\begin{tabular}{|c|c|c|c|c|c|c|c|c|c|c|}
\hline \multirow{2}{*}{$\begin{array}{c}\text { \# state- } \\
\text { ment }\end{array}$} & \multicolumn{10}{|c|}{ Medians of Assessment } \\
\hline & Norm & F20.0 & F.34.0 & F34.1 & F40-F48 & F10 & F11 & F70 & F71 & F84.5 \\
\hline 44 & 4 & 1 & 4 & 3 & 4 & 4 & 3 & 4 & 3 & 2 \\
\hline 45 & 3 & 1 & 4 & 3 & 4 & 4 & 4 & 3 & 4 & 2 \\
\hline 46 & 3 & 2 & 4 & 3 & 3 & 4 & 3 & 4 & 4 & 3 \\
\hline 48 & 4 & 4 & 4 & 2 & 4 & 4 & 3 & 3 & 1 & 3 \\
\hline 50 & 3 & 2 & 4 & 2 & 3 & 4 & 3 & 2 & 0 & 2 \\
\hline 1 & 2 & 0 & 3 & 1 & 2 & 2 & 2 & 1 & 0 & 1 \\
\hline 2 & 2 & 1 & 3 & 1 & 2 & 3 & 1 & 3 & 4 & 0 \\
\hline 15 & 1 & 0 & 3 & 1 & 1 & 1 & 1 & 2 & 3 & 3 \\
\hline 21 & 2 & 0 & 3 & 1 & 2 & 2 & 2 & 3 & 3 & 1 \\
\hline 22 & 1 & 2 & 2 & 1 & 1 & 2 & 1 & 2 & 1 & 1 \\
\hline 30 & 1 & 0 & 2 & 0 & 1 & 1 & 1 & 0 & 0 & 0 \\
\hline 35 & 1 & 0 & 2 & 1 & 1 & 1 & 1 & 0 & 2 & 1 \\
\hline 39 & 2 & 1 & 3 & 1 & 2 & 2 & 1 & 3 & 3 & 3 \\
\hline 49 & 1 & 0 & 2 & 0 & 1 & 1 & 1 & 2 & 3 & 0 \\
\hline 4 & 0 & 0 & 0 & 0 & 0 & 0 & 0 & 0 & 2 & 0 \\
\hline 6 & 0 & 0 & 0 & 0 & 0 & 0 & 0 & 0 & 0 & 0 \\
\hline 11 & 0 & 0 & 1 & 0 & 0 & 0 & 0 & 0 & 2 & 0 \\
\hline 16 & 0 & 0 & 0 & 0 & 0 & 0 & 0 & 0 & 0 & 0 \\
\hline 19 & 0 & 1 & 1 & 0 & 0 & 0 & 0 & 0 & 2 & 0 \\
\hline 23 & 0 & 1 & 1 & 0 & 0 & 0 & 0 & 0 & 0 & 0 \\
\hline 26 & 0 & 0 & 0 & 0 & 0 & 0 & 0 & 0 & 0 & 0 \\
\hline 43 & 0 & 0 & 0 & 0 & 0 & 0 & 0 & 0 & 0 & 0 \\
\hline 47 & 0 & 0 & 0 & 0 & 0 & 0 & 0 & 0 & 1 & 0 \\
\hline
\end{tabular}

Note. In Table 1\&2, numbers of statements, assessed by the group of conventional norm as "funny", are marked in bold, "not very funny" - in normal font, "neutral" - in italics.

Table 2 presents the information about the significance of differences between the group of conventional norm and different groups of people with mental disorders.

The differences between the perception of humour by people

with mental disorders and the group of conventional norm

\begin{tabular}{|c|c|c|c|c|c|c|c|c|c|}
\hline \multirow{2}{*}{$\begin{array}{c}\text { № state } \\
\text { ment }\end{array}$} & \multicolumn{9}{|c|}{ Mann-Whitney Criterion U } \\
\hline & $\begin{array}{c}\text { F20.0 - } \\
\text { norm }\end{array}$ & $\begin{array}{c}\text { F34.0 - } \\
\text { norm }\end{array}$ & $\begin{array}{c}\begin{array}{c}\text { F34.1- } \\
\text { norm }\end{array} \\
\text { ent }\end{array}$ & $\begin{array}{c}\text { F40- F48- } \\
\text { norm }\end{array}$ & F10- norm & F11- norm & F70- norm & F71- norm & $\begin{array}{c}\text { F84.5- } \\
\text { norm }\end{array}$ \\
\hline 5 & $-2,772 * *$ & $-3,218 * *$ & $-2,808 * *$ & $-0,011$ & $-1,717$ & $-0,783$ & $-2,781 * *$ & $-4,228 * *$ & $-0,017$ \\
\hline 7 & $-0,391$ & $-2,914 * *$ & $-1,890$ & $-0,423$ & $-2,777 * *$ & $-1,744$ & $-1,111$ & $-3,818 * *$ & $-0,446$ \\
\hline 10 & $-0,396$ & $-1,265$ & $-7,602 * *$ & $-0,652$ & $-0,229$ & $-0,340$ & $-1,342$ & $-5,934 * *$ & $-1,652$ \\
\hline 12 & $-3,864 * *$ & $-4,068 * *$ & $-1,697$ & $-0,232$ & $-0,443$ & $-0,966$ & $-1,617$ & $-1,212$ & $-1,238$ \\
\hline 13 & $-5,050 * *$ & $-0,112$ & $-1,862$ & $-1,046$ & $-0,131$ & $-0,770$ & $-0,892$ & $-4,981 * *$ & $-1,148$ \\
\hline 14 & $-7,859 * *$ & $-0,916$ & $-6,854 * *$ & $-0,793$ & $-0,438$ & $-1,315$ & $-0,414$ & $-6,618 * *$ & $-0,798$ \\
\hline 18 & $-3,911 * *$ & $-4,102 * *$ & $-1,218$ & $-1,113$ & $-0,230$ & $-3,087 * *$ & $-0,538$ & $-0,572$ & $-1,133$ \\
\hline 24 & $-0,338$ & $-1,114$ & $-3,014 * *$ & $-1,258$ & $-0,019$ & $-0,132$ & $-1,898$ & $-1,113$ & $-1,266$ \\
\hline 25 & $-1,892$ & $-1,608$ & $-4,467 * *$ & $-1,462$ & $-0,257$ & $-1,006$ & $-0,916$ & $-5,002 * *$ & $-1,464$ \\
\hline 29 & $-0,819$ & $-1,816$ & $-1,718$ & $-0,344$ & $-0,664$ & $-0,793$ & $-0,316$ & $-2,828 * *$ & $-0,849$ \\
\hline 32 & $-5,039 * *$ & $-1,077$ & $-1,694$ & $-0,232$ & $-0,091$ & $-1,113$ & $-1,794$ & $-4,846 * *$ & $-0,244$ \\
\hline 34 & $-3,404 * *$ & $-0,936$ & $-8,412^{* * *}$ & $-0,447$ & $-0,078$ & $-1,258$ & $-0,611$ & $-7,627 * *$ & $-0,453$ \\
\hline 36 & $-0,184$ & $-2,802 * *$ & $-1,118$ & $-0,231$ & $-0,148$ & $-1,462$ & $-1,631$ & $-1,515$ & $-0,231$ \\
\hline 38 & $-0,533$ & $-2,935 * *$ & $-1,781$ & $-0,444$ & $-0,656$ & $-0,344$ & $-1,544$ & $-1,769$ & $-1,456$ \\
\hline 40 & $-8,890 * *$ & $-0,581$ & $-3,864 * *$ & $-0,230$ & $-0,986$ & $-0,232$ & $-1,612$ & $-8,914 * *$ & $-1,115$ \\
\hline 41 & $-0,126$ & $-3,735 * *$ & $-1,142$ & $-0,018$ & $-0,227$ & $-0,447$ & $-0,798$ & $-3,559 * *$ & $-2,966 * *$ \\
\hline 44 & $-4,642 * *$ & $-0,128$ & $-1,388$ & $-0,257$ & $-0,608$ & $-1,325$ & $-0,448$ & $-2,893 * *$ & $-0,232$ \\
\hline 45 & $-3,436^{* *}$ & $-0,924$ & $-0,166$ & $-0,638$ & $-3,015 * *$ & $-1,220$ & $-1,164$ & $-1,340$ & $-0,128$ \\
\hline 46 & $-3,602 * *$ & $-2,953 * *$ & $-1,146$ & $-0,096$ & $-1,065$ & $-0,573$ & $-1,635$ & $-1,647$ & $-0,264$ \\
\hline 48 & $-0,896$ & $-0,098$ & $-5,362 * *$ & $-0,174$ & $-1,003$ & $-1,008$ & $-0,558$ & $-7,231 * *$ & $-0,835$ \\
\hline 50 & $-1,878$ & $-4,004 * *$ & $-1,178$ & $-0,449$ & $-2,918 * *$ & $-0,008$ & $-1,414$ & $-7,746 * *$ & $-0,197$ \\
\hline 1 & $-2,781 * *$ & $-2,818^{* *}$ & $-0,497$ & $-0,463$ & $-0,249$ & $-0,232$ & $-0,759$ & $-4,212 * *$ & $-0,176$ \\
\hline 2 & $-2,930 * *$ & $-2,844 * *$ & $-0,890$ & $-0,138$ & $-0,673$ & $-1,046$ & $-1,238$ & $-3,770 * *$ & $-0,469$ \\
\hline 15 & $-3,616^{* *}$ & $-7,412^{* *}$ & $-0,361$ & $-0,489$ & $-0,173$ & $-0,793$ & $-1,862$ & $-2,936 * *$ & $-1,178$ \\
\hline 21 & $-2,835 * *$ & $-1,764$ & $-1,719$ & $-0,260$ & $-0,449$ & $-1,113$ & $-1,615$ & $-1,729$ & $-0,662$ \\
\hline 22 & $-4,212 * *$ & $-1,889$ & $-1,448$ & $-0,313$ & $-0,233$ & $-1,272$ & $-1,680$ & $-1,438$ & $-0,232$ \\
\hline 30 & $-1,870$ & $-1,448$ & $-1,306$ & $-0,258$ & $-0,017$ & $-1,468$ & $-0,914$ & $-1,992$ & $-1,312$ \\
\hline 35 & $-0,968$ & $-0,996$ & $-1,704$ & $-0,630$ & $-0,257$ & $-0,344$ & $-1,016$ & $-0,893$ & $-1,402$ \\
\hline 39 & $-2,822 * *$ & $-2,790 * *$ & $-2,008^{*}$ & $-0,096$ & $-0,666$ & $-1,232$ & $-1,222$ & $-4,003 * *$ & $-1,241$ \\
\hline
\end{tabular}

Science and Education, 2017, Issue 7 


\begin{tabular}{|c|c|c|c|c|c|c|c|c|c|}
\hline \multirow{2}{*}{$\begin{array}{c}\text { \# state- } \\
\text { ment }\end{array}$} & \multicolumn{9}{|c|}{ Mann-Whitney Criterion U } \\
\hline & $\begin{array}{c}\text { F20.0 - } \\
\text { norm }\end{array}$ & $\begin{array}{c}\text { F34.0 - } \\
\text { norm }\end{array}$ & $\begin{array}{c}\text { F34.1- } \\
\text { norm }\end{array}$ & $\begin{array}{c}\text { F40- F48- } \\
\text { norm }\end{array}$ & F10- norm & F11- norm & F70- norm & F71- norm & $\begin{array}{l}\text { F84.5- } \\
\text { norm }\end{array}$ \\
\hline 49 & $-3,414 * *$ & $-1,618$ & $-0,981$ & $-0,074$ & $-0,092$ & $-0,449$ & $-0,118$ & $-0,389$ & $-0,515$ \\
\hline 4 & $-0,679$ & $-0,092$ & $-0,361$ & $-0,189$ & $-0,074$ & $-0,484$ & $-0,655$ & $-0,192$ & $-0,913$ \\
\hline 6 & $-0,513$ & $-0,381$ & $-0,212$ & $-0,678$ & $-0,131$ & $-1,049$ & $-0,081$ & $-0,684$ & $-1,361$ \\
\hline 11 & $-1,016$ & $-3,154 * *$ & $-0,094$ & $-0,894$ & $-0,674$ & $-0,313$ & $-0,196$ & $-0,984$ & $-1,008$ \\
\hline 16 & $-0,483$ & $-0,916$ & $-0,895$ & $-0,455$ & $-0,687$ & $-1,713$ & $-0,489$ & $-0,657$ & 1,715 \\
\hline 19 & $-1,212$ & $-4,606^{* *}$ & $-0,381$ & $-1,314$ & $-0,129$ & $-1,258$ & $-0,663$ & $-1,318$ & $-0,964$ \\
\hline 23 & $-1,605$ & $-2,912 * *$ & $-1,009$ & $-1,505$ & $-0,189$ & $-1,462$ & $-0,131$ & $-1,555$ & $-1,452$ \\
\hline 26 & $-0,788$ & $-1,015$ & $-1,362$ & $-0,772$ & $-0,271$ & $-0,344$ & $-0,889$ & $-0,779$ & $-0,013$ \\
\hline 43 & $-1,312$ & $-1,625$ & $-0,843$ & $-0,414$ & $-0,874$ & $-0,248$ & $-1,114$ & $-0,424$ & $-0,246$ \\
\hline 47 & $-1,691$ & $-0,894$ & $-0,789$ & $-1,003$ & $-0,888$ & $-0,461$ & $-1,435$ & $-1,334$ & $-0,441$ \\
\hline
\end{tabular}

According to Table 2, the most significant differences in the assessment of the statements in comparison with the conventional norm were found in groups of individuals with paranoid schizophrenia, cyclotemia, dysthymia, mental retardation of moderate degree.

\section{Interpretation of the Results}

In the group of people with "paranoid schizophrenia", the differences in the assessment of humorous and neutral phrases were discovered compared with the group of conventional norm. Phrases: 5, 12, 13, 14, 18, 32, 34, $40,44,45,46$ were assessed by the group of conventional norm as definitely "funny" (they got 3 or 4 points), and individuals with paranoid schizophrenia gave them lower points [Annex A]. Some of them were assessed in 3 points, while the members of the group of conventional norm assessed them in 4 points.

However, most of the mentioned phrases were assessed by the analysed group as "not very funny". Similarly, the phrases which were assessed by the members of conventional norm as "not very funny", were assessed lower in 1 point or as "neutral" by the members of the analysed group.

Thus, this group of people has specific perception of humorous information that distinguishes them among others. All the phrases, according to which we revealed significant differences, were assessed lower by the participants of the analysed group. The way the respondents commented some phrases, reflect the specificity of their perception of humour.

For example, one of the respondents assessing the phrase "Is it your skirt or belt?" explained: "There is nothing funny. It is possible to use a wide belt as a skirt and a skirt as a belt". Another statement "I am bored. I want to sleep with you" was explained by one of the respondents as follows: "One cannot laugh when he/she wants to sleep. This phrase cannot be assessed more than in 2 points". The explanations reflect the impact on the perception of humorous side associations and different style of thinking of the respondents that, obviously, reduces the humorous effect of the perceived content to a great degree.

The respondents with paranoid schizophrenia have a tendency to underestimate the humorous content of the suggested phrases, and the participants with cyclotemia, by contrast, have a tendency to overestimate humour of the statements. Moreover, it should be noted that they assessed not only phrases from categories "funny" and "not very funny", but also "neutral" phrases higher than the respondents of the control group.

Some phrases, assessed by the control group as "funny", were assessed much higher by the respondents with cyclotemia (such phrases as 5, 7, 12, 18, 36, 38, 41, 46, 50) [Annex A]. In addition, the following phrases were assessed by the participants of the control group as "not very funny" but the patients with cyclotemia considered them to be "funny": 1, 2, 15, 39.

$11,19,23$ phrases that, according to people of conventional norm, are neutral, were evaluated by the analysed group as "not very funny" [Annex A].

Here is an example of the female respondent's explanation of one of the statements: "The Cat (male) that walked on his own", is ridiculous. In the old days 'cat used to walk on her own', and now he does the same (male cat)". Another example relates to the phrase "Happy New Year!" The respondent considers this statement "not very funny" but not "neutral", explaining: "The New Year is the funniest holiday, and even mentioning of it is amusing" [Annex A]. The most frequently the respondents of this group could not explain their assessment; they just mentioned that it was funny and without thinking, evaluated them higher compared to the participants of the control group.

The nature of the assessment of humorous and neutral content, emotional, verbal and nonverbal reactions by this group's members reveals specific to this category of patients parameters of perception of humour. First of all, it is reducing the criticality of humorous content, a tendency to overestimating the level of humour, influence on the perception of random associations, the inability to focus on significant moments of humorous content.

Analysing the survey results of the respondents with "dysthymia" we have noticed a reverse trend in perception of humour. They, as well as people with paranoid schizophrenia have a tendency to underestimate the level of humour. Nevertheless, the psychological nature of this inclination is slightly different.

If people with schizophrenic disorders have specific properties of thinking combined with distortion and decrease in affective areas [62], the respondents with dysthymia disorders are characterized by reducing the level of motives and desires, lack of energy aspects of the psyche for adequate responding to humour. 
Humour for individuals with depressive states are, in some sense, an "excessive", "redundant" phenomenon, as it requires additional mental efforts to understand its content and to participate in the intellectual game, which can be provided. $5,10,14,24,25,34,40,48$ and 39 phrases were assessed lower by the participants with dysthymia than by the members of the group of conventional norm [Annex A].

The group of people with neurotic, stress-related and somatoform disorders has no significant differences in the assessment of humorous statements compared with the group of conventional norm. Of course, it does not mean that such differences do not exist. Obviously, for their distinguishing it is necessary to use more delicate and sensitive psychodiagnostic tools that can be considered as the prospect of further research. It should be noted that by the criterion of the perception of humorous content, the analysing group is more similar to the group of conventional norm than other groups of people with mental disorders.

In the group of people with MBDPSU, we have revealed some differences compared to the group of conventional norm according to certain phrases. In the group of people with MBDAU the differences in the assessment of three humorous phrases: 7, 45, 50 are observed [Annex A]. In all these cases, the respondents with MBDAU overestimated humorous phrases. In the group of people with MBDOU overestimation is observed only in the phrase 18 [Annex A].

A tendency to overestimating the level of humour content is probably associated with the development of psychological defence mechanisms, where the use of humour is one of their elements. Unserious attitude to serious problems is specific to people with MBDPSU, with the functioning of the mechanism of rejection.

Obviously, such a psychological tendency is observed in perception of not only serious content as lighthearted, but also humorous content as "more humorous".

People with mental retardation of light degree show a tendency to underestimating. However, significant differences were detected only in respect of one phrase -5 [Annex A].

Clearly this tendency is manifested by individuals with mental retardation of moderate degree. Phrases 5, 7, $10,13,29,32,34,40,41,44,48,50$ which were assessed as "funny" by the members of the group of conventional norm, were greatly underestimated by the analysed group [Annex A]. The same situation is applied to phrase 1 and 2 that under normal conditions were assessed as "not very funny". Individuals with mental retardation of moderate degree assessed them lower. At the same time phrases: $14,15,25,39$ were overestimated by them [Annex A].

In general, the tendency to the underestimating of humorous phrases with certain cases of overestimating means insufficient understanding of humorous content. The group of people with mental retardation of moderate degree assessed humorous phrases often by "trials and errors" based on personal experience, certain situational associations, etc.

According to the respondents' explanations it was clear that the phrases were assessed without understanding their meanings. For example, one of them commented the phrase "The thought has left his mind, not being able to put up with loneliness" as follows: "one should always think, even if he/she is alone" [Annex A].

We have revealed the dependence of the perception of humour on the level of intelligence in people with mental retardation. In order to understand the humorous content a person should be familiar with the system of cultural meanings, have certain educational level, as well as to be able to generalize and abstract.

It is clear that people with mental retardation of moderate degree failure according to all these parameters. And, obviously, this level of mental retardation is a kind of boundary where understanding of humour cannot be adequate.

The respondents with Asperger syndrome have a significant difference compared to the group of conventional norm in the assessment of just one phrase: 41 [Annex A]. The medians of assessment of other phrases often vary downward and upward, however, significant differences have not been found. Thus, by means of The Assessment of Humorous Statements Inventory, the specificity of perception of humour by individuals with Asperger syndrome has not been revealed.

\section{Conclusion}

Perception of humour by individuals, who represent different nosological forms, is different as compared to the conventional norm and different groups between each other.

- Participants with paranoid schizophrenia and dysthymia show an exact tendency to underestimating the humour of phrases. The comments by people with paranoid schizophrenia reflect the impact on the perception of humour side of associations, various thinking and distortion of affective sphere. The explanations of people with dysthymia show the reduction of motives and desires, lack of energy aspects of psyche to adequate respond to humour.

- The patients with cyclotemia show a tendency to overestimate the humour of the proposed content; the nature of their assessments reflects the decline of criticality for humorous content, influence on the perception of random associations, the inability to focus on essential points.

- Participants with MBDPSU, show a slight tendency to overestimating humour, manifested in their use of certain aspects of humorous behaviour as defence strategies.

- People with mental retardation of light degree show a tendency to underestimating some humorous phrases and overestimating others. Precisely this tendency is manifested by individuals with mental retardation of moderate degree and reflects, above all, the lack of understanding of humorous content. The phrase assessment by 
individuals with mental retardation of moderate degree is often performed by the method of "trials and errors", without sufficient understanding of the content, based on specific situational ties.

\section{REFERENCES}

1. Ivanova, E. M. (2008). Narusheniye raspoznavaniya yumora $\mathrm{u}$ bolnykh shizofreniey [Violation of humour perception by patients with schizofrenia]. Psihologicheskiy zhurnal - Psychological Journal, (Vol. 29), 6, 75-81 [in Russian].

2. Ivanova, E. M. (2008). Narusheniya chuvstva yumora pri shizofrenii i affektivnyh rasstroystvah [Violation of humour while schizophrenia and affective disorders]. Voprosy psikhologii - Issues of Psychology, 1, 4557 [in Russian].

3. Kovjazina, M. S. (2008). Vospriyatie yumora bolnymi s lokalnymi porazheniyami mozga [Perception of humour by patients with local disease of the brain], $V o$ prosy psikhologii - Issues of Psychology, 2, 74-82 [in Russian].

\section{ЛІТЕРАТУРА}

1.Иванова Е. М. Нарушение распознавания юмора у больных шизофренией / Иванова Е. М., Ениколопов С. Н., Митина О. В. // Психологический журнал. 2008. - Т. 29, № 6. - С.75-81.

2.Иванова Е. М. Нарушения чувства юмора при шизофрении и аффективных расстройствах / Иванова Е. М., Ениколопов С. Н., Митина О. В. // Вопросы психологии. - 2008. - № 1. - С. 45-57.

3. Ковязина М. С. Восприятие юмора больными с локальными поражениями мозга / М. С. Ковязина, М. А. Коган // Вопросы психологии. - 2008. - № 2. C. 74-82.

4.Falkenberg I. Sense of humor in patients with schizophrenia / I. Falkenberg, K. Klu gel, M. Bartels, B. Wild // Schizophrenia Research. - 2007. - 95. - P. 259-261.
- Groups of people with neurotic, stress-related and somatoform disorders and Asperger syndrome do not show significant differences in the assessment of humorous content as compared to the participants of the group of conventional norm.

4. Falkenberg, I. (2007). Sense of humour in patients with schizophrenia. Schizophrenia Research, 95, 259-261 [in English].

5. Gillikan, L. S. (1991). Humor Appreciation and Mood in Stroke Patients. Cognitive Rehabilitation, 9, 3035 [in English].

6. Ruch, W. (1992). Assessment of appreciation of humor: Studies with the 3 WD humor test. Advances in Personality Assessment. Hillsdale.NJ: Erlbaum, 9, 27-75 [in English].

7. Samson, A. C. (2010). Perception of aggressive humor in relation to gelotophobia, gelotophilia, and katagelasticism. Psychological Test and Assessment Modeling, 52, 217-230 [in English].

8. Suls, J. M. (1983). Cognitive processes in humor appreciation. P. E. McGhee \& J. H. Goldstein (Eds.), Vol. 1: Basic issues, 39-57 [in English].

5.Gillikan L. S. Humor Appreciation and Mood in Stroke Patients / L. S. Gillikan, P. Derks // Cognitive Rehabilitation. - 1991. - № 9. - P. 30-35.

6. Ruch W. Assessment of appreciation of humor: Studies with the 3 WD humor test / W. Ruch // Butcher J. N., Spielberger C. D. (eds.) Advances in Personality Assessment. Hillsdale. - NJ: Erlbaum, 1992. - № 9. - P. 27 75 .

7. Samson A. C. Perception of aggressive humor in relation to gelotophobia, gelotophilia, and katagelasticism / A. C. Samson, Y. Meyer // Psychological Test and Assessment Modeling. - 2010. - 52. - P. 217-230.

8. Suls J. M. Cognitive processes in humor appreciation / J. M. Suls // Handbook of humor research / P. E. McGhee \& J. H. Goldstein (Eds.) . - 1983. - Vol. 1: Basic issues. - P. 39-57.

\section{Humorous Statements Assessment Inventory (by M. Koviazina and M. Kohan)}

Annex A

NotaBene: humor of most phrases is based on the word-play in the Russian language, so that the humorous content of some statements may be lost as a result of translation).

1. Призвание хорошо, а звание лучше - Vocation is good but profession is better (Humor is based on untranslatable wordplay).

2. Замолчи! Ну что ты пишешь! - What the hell are you writing?! Shut up!

3. Чем дальше хочешь прыгнуть, тем ниже нужно согнуться - The further one wants to jump, the lower he/she needs to bend.

4. Рыба плещется в волнах - Fish is splashing in
5. Стояла тихая Варфоломеевская ночь - There was a quiet Bartholomew's night.

6. Родственников и друзей надо поздравлять с праздниками - Relatives and friends should be sent holiday greetings.

7. Мысль покинула голову, не выдержав одиночества - A thought left his mind, not being able to put up with loneliness. waves. 
8. Лишь тяжелый кошелек позволяет угнаться за модой - Only a heavy purse makes it possible to keep up with fashion.

9. Если у вас чешутся руки, то почешите в другом месте - If your fingers itch to do something, scratch somewhere else.

10. За песни под фонограмму надо платить ксерокопиями денег - For songs with phonogram, one should be pay with photocopies of money.

11. Мама убирала квартиру, а дети играли на улице - While mother was cleaning up the apartment, her children were playing in the street.

12. Акция! Купите один ботинок и в подарок получаете второй! - Sale! Buy one shoe and get a second one as a present!

13. Морская качка изображена художником с таким сходством, что при одном взгляде на картинку тошнило - Ship motion is depicted by the artist with such a similarity that at the sight of it one can feel sick.

14. Дурак, совершенствуясь, становится круглым - A fool improving is getting blooming (based on the world-play).

15. Кот, который гулял сам по себе - The cat that walked on his own.

16. Лучше поздно, чем никогда - Better late than never.

17. Выпился в алкоголики - He has drunk his way in alcoholism (the translation is based on the phrase "make one's way in life").

18. Деньги - зло. Когда приходишь в магазин, зла не хватает! - Money is root of all evil. It burns a hole in our pockets every time we need it (Humor is based on untranslatable wordplay).

19. С новым годом! - Happy New Year!

20. Только в очень хорошем настроении она называла получку мужа деньгами - Only in a very good mood she called her husband's salary money.

21. Бог создал женщин глупыми, чтобы они любили мужчин - God created women silly so that they loved men.

22. Крик моды понятнее всего на иностранном языке - The last word in fashion is the most clearly understandable in a foreign language. today.

23. Сегодня хорошая погода - The weather is fine

24. Перья у писателя были - ему не хватало крыльев - The writer had feathers (quills) but he lacked wings (In the Russian language, a quill is the same as a feather, the humor is based on the homonyms).

25. Чего милиции не хватает, так это рубле непробиваемых жилетов - The only thing our militia lacks is ruble-proof vests.

26. В то утро солнечные лучи нежно светили в комнату - That morning the sun's rays glowed gently into the room.

27. Реплика: «Собаки - тоже люди» - Dogs are people, too.
28. Поярче надо на мел нажимать! - You should press the chalk more brightly!

29. Неграм очень нравится фильм «Чапаев», особенно фраза «Всех белых вырежем - и настанет счастливая жизнь!» - Black people enjoy the movie "Chapaiev" very much, especially the phrase "We will cut out all the white - and a happy life will come!"

30. Русские просторы всегда радуют глаз - Russian open landscapes are inviting to an eye.

31. Жена шефа много лучше, чем шеф жены The boss's wife is much better than the wife's boss.

32. Это у тебя юбка или пояс? - Is it a skirt or belt on you?

33. Новое почетное звание: «Почетный слуга народа» - The new honorary title "The honored servant of people."

34. Любите внуков - они отомстят вашим детям - Love your grandchildren - they will take revenge on your children.

35. Спутник славы - одиночество - The companion of glory is loneliness.

36. Не бойтесь этой гранаты - она ручная - Do not be afraid of this hand-grenade. It is tame (In the Russian language, "hand" and "tame" are homonyms).

37. Сегодня отрабатываем одевание и раздевание противогаза. - Today we practice "dressing" and "undressing" the gas mask (Based on the similarity of the Russian phrases "put on" and "dress").

38. Когда она заговорила о чернобурой лисе, муж посмотрел на нее волком - When she started talking about a silver fox fur, the husband glared at her like a tiger.

39. Красота - страшная сила - Beauty is a weapon of mass distraction (literary: Beauty is a terrible power, based on the Russian aphorism).

40. «Удивительное - ядом» - Сказал Сальери. One man's meat is another man's poison - Salieri said (Humor is based on the wordplay on the Russian aphorism).

41. Новый «Чаппи» со вкусом академика Павлова - для собак, которые помнят - The new Academician Pavlov-flavored "Chappi" - for dogs who remember.

42. Из сводки новостей: «Закончились рождественские бомбардировки Багдада». - From the news headline: "Christmas bombing of Baghdad has ended."

43. Чай в пять часов - чисто английская традиция - Five o'clock tea is a pure English tradition.

44. «Дети! Смотрите на меня внимательно, а то не будете иметь представления об обезьяне» "Children! Look at me attentively; otherwise you will not have an idea of a monkey."

45. Если жена не следит за модой, за ней можно не следить - If your wife does not follow fashion trends, there is no need to follow her.

46. Мне с вами скучно, мне с вами спать хочется - I'm bored with you, I would better sleep with you.

47. Цыплят по осени считают - Never count your chickens before they hatch. 
48. Когда музы молчат, говорят жены поэтов When muses keep silent, the poets' wives talk.

49. Кошки охотятся на мышей, а мыши их боятся - Cats chase mice, and mice are afraid of them.
50. Многие женятся по любви, потому что не имеют возможности жениться по расчету - Many people get married for love just because they do not have an opportunity to marry for convenience.

Наталя Свгенівна Дмітренко, кандидат педагогічних наук, доцент кафедри іноземних мов, Вінницький державний педагогічний університет імені Михайла Кочююбинського, вул. Острозького, 32, м. Вінниця, Україна,

Людмила Францівна Крупельницька, доктор психологічних наук, дочент кафедри психодіагностики та клінічної психології, Київський начіональний університет імені Тараса Шевченка, м. Київ, Украӥна,

Оксана Миколаӥвна Шиортун, кандидат педагогічних наук, докторант кафедри психодіагностики та клінічної психології,

Киівський начіональний університет імені Тараса Шевченка, 16, бульвар Шевченка, м. Київ, Украӥна

\section{СПРИЙМАННЯ ГУМОРИСТИЧНОГО ЗМІСТУ У НОРМІ ТА ПРИ ПСИХІЧНІЙ ПАТОЛОГІЇ}

У статті представлено результати дослідження сприймання гумористичного змісту особами, що належать до групи умовної норми, а також особами з психічними розладами. Подано опис вибірки та методики дослідження. У дослідженні використано методику “Оцінка гумористичних тверджень”, розроблену М. С. Ковязіною та М. А. Коганом [3]. Установлено, що сприймання гумору в осіб, що представляють різні нозологічні форми, виявляе відмінності як у порівнянні з групою умовної норми, так і у порівнянні різних груп між собою. Оскільки специфіка сприймання гумористичного змісту в осіб умовної норми та осіб із різними психічними розладами є неоднаковою, використання гумору матиме психодіагностичну направленість у виявленні певних психічних патологій. Сприймання гумору в осіб, що представляють різні нозологічні форми, виявляє відмінності як у порівнянні з групою умовної норми, так і у порівнянні різних груп між собою. Досліджувані з параноїдною шизофренією та дистимією виявляють виражену тенденцію до недооцінки гумористичності фраз. При цьому пояснення осіб з параноїдною шизофренією відображають вплив на сприймання гумору побічних асоціацій, різноплановості мислення та викривлення афективної сфери. Пояснення ж осіб з дистимією відображають зниження рівня спонукать та потягів, недостатність енергетичних аспектів психіки для адекватного реагування на гумор. Досліджувані з циклотимією виявляють тенденцію до переоцінки гумористичності запропонованого змісту; характер їх оцінок відбиває зниження критичності щодо гумористичного змісту, вплив на сприйняття випадкових асоціацій, нездатність зосередитись на істотних моментах змісту. Досліджувані 3 ППРВВПАР виявляють незначну тенденцію до переоцінки гумористичності, що відбиває використання ними певних аспектів гумористичної поведінки у якості захисних стратегій. Особи з розумовою відсталістю легкого ступеня виявляють тенденцію до недооцінки одних гумористичних фраз та переоцінки - інших. Чіткіше ця тенденція виявляється у осіб з розумовою відсталістю помірного ступеня та відображає, насамперед, недостатнє розуміння гумористичного змісту. Виконання завдання на оцінку гумористичності фраз досліджуваними 3 помірною розумовою відсталістю часто виконується методом «проб та помилок», без достатнього розуміння змісту, з опорою на конкретно-ситуаційні зв'язки. За групами осіб з невротичними, пов'язаними зі стресом та соматоформними розладами та з синдромом Аспергера, значимих відмінностей в оцінках гумористичного змісту, у порівнянні з оцінками учасників групи умовної норми, не виявлено.

Ключові слова: сприймання гумору, гумористичний зміст, група умовної норми, група осіб з психічними розладами. 